\title{
Impact of Coal Based Power Plants: A Comparative Study on Assessment of Pattern of Illnesses among People Living in The Vicinity of Coal-Based Power Plant Area and Non Power Plant Area \\ Original Article
}

Authors

\author{
Dr Jyoti Tiwari ${ }^{1}$, Dr A. R. Tyagi ${ }^{2}$, Dr P. K. Kasar ${ }^{3}$ \\ ${ }^{1}$ Resident, Dept of Community Medicine, NSCB Medical College Jabalpur, India \\ ${ }^{2}$ Assistant Professor, Dept of Community Medicine, NSCB Medical College Jabalpur, India \\ ${ }^{3}$ Professor \& Head, Dept of Community Medicine, NSCB Medical College Jabalpur, India \\ Corresponding Author
}

Dr Jyoti Tiwari

Resident, Dept of Community Medicine, NSCB Medical College Jabalpur, India

Email:drj.tiwaril @ gmail.com, Mobile:09425841796

\begin{abstract}
Introduction: Fossil fuels are the main source of energy. Various byproducts and toxicants generated through the coal based power plants may have the deleterious effects on the health of the nearby inhabitants and also affecting the flora and fauna of the adjoining area.

Aim \& Objective: To know the impact of coal based power plant on nearby human population by assessing the risk to various illnesses.

Method: A cross-sectional study was carried out in 6 villages of power plant area and 6 villages of non power plant area. We compared each findings of power plant area with that of non-plant area by obtaining relative risk for power plant area compared to non-plant area.

Observations: In this study all kind of illnesses were found more in coal based power plant area. 448 [38.5\%] persons had some kind of illness in power plant area and 99 [8.4\%] persons had some kind of illness in non-plant area. Among ill, maximum $47.5 \%$ population had respiratory illness.

Conclusion: All of us are at risk for exposure to pollutants from power plant as the consequences of emission from power plants are diffused over ten to tens of thousands of miles, tens of years, and over tens of millions of victims.
\end{abstract}

Key words: coal, power plant, vicinity

\section{Introduction}

Fossil fuels are the main source of energy. Coal is the only natural resource available in abundance in India. Consequently, it is used widely as a thermal energy source for thermal power plants producing electricity. India has about 90,000 MW installed capacity for electricity generation, of which more than $70 \%$ is produced 
by coal-based thermal power plants. ${ }^{[1]}$ Various byproducts and toxicants generated through the use of coal may have the deleterious effects on the health of the nearby inhabitants and also affecting the flora and fauna of the adjoining area, thus destabilizing the ecosystem and wildlife. This occurs in a variety of ways, at which humans have been exposed to coal waste toxics, whether from breathing "fugitive dust", drinking contaminated water, eating contaminated vegetable and eatables like fish, or by direct contact with skin. ${ }^{[2]}$

Coal waste most importantly is coal ash and exhaust gases containing toxic gases along with particulate matter emitted from coal fired power plants. ${ }^{[3]}$ The people of all age groups living in the vicinity of coal based power plant area are especially vulnerable for various types of illnesses ranging from allergic conditions to severe respiratory diseases like pneumoconiosis. They can trigger diseases of nearly all the systems of body leads to premature death ${ }^{[2]}$ Also benzene soluble material in the ambient air ranged from 45 to $60 \%$. This indicate probable health hazard due to carcinogenic nature of PM. ${ }^{[2]}$

At present in the developing country like India many coal ash disposal sites are located in rural areas, where land availability and lower land prices make it cheap to purchase the multi-acre sites necessary for ash ponds and landfills. Lowincome communities living near a disproportionate share of coal ash disposal facilities may be exposed both during ash unloading and subsequently due to windblown emissions. $^{[4][5]}$

Some diseases may become irreversible, but most of the illnesses can be prevented if suitable measures are taken at different levels (personal, environmental, Government). ${ }^{[5]}$ Therefore, the assessment of disease burden on the people due to continuous exposure to the hazardous environment in the vicinity of coal based power plant is essential and making the comparison with people of non power plant area can usher to the inferences for causation of prevailing illnesses as well as finding out the measures for control and prevention in future.

Our Endeavour is to study the existing illnesses of people living in the vicinity of coal based power plant and help them to mitigate their health problems arising out from exposure to different toxicants.

\section{Objectives}

1. To find out the pattern and burden of illnesses among people living in the vicinity of coal based power plant area.

2. To find out the risk association with proximity to coal ash pond in power plant area.

3. To compare the pattern of illnesses among the residents of coal-based power plant area and non-power plant area.

\section{Method}

A cross-sectional study was carried out in 6 villages of power plant area and 6 villages of non power plant area. Data was collected in the month of May 2012 at both the areas.

The villages of coal based Power plant area Singrauli were selected according to the radial distances from reference point [coal ash pond / Govind Ballabh Pant Sagar - a large Reservoir of Water on Rihand River, which is a source of water supply and disposal site for coal ash slurry for plant]. 2 villages at each were taken respectively at $0-3 \mathrm{~km}, 5-6 \mathrm{~km}$ and $8-10 \mathrm{~km}$ from coal ash pond heading towards North-West direction. As comparison group 6 villages from rural area of Jabalpur were taken, assuming that selected households from the villages of Singrauli and Jabalpur will have same socio-demographic profile.

Sample size: We decided to cover $20 \%$ of households from each village. As each village has on an average 150 to 200 households (census 2011 maps of India), so 40 households were taken from each village for survey. In total 240 households were covered from 6 villages. All members of households were included in study. 


\section{Analysis}

Data was entered in Microsoft Excel 2007 and analyzed by generation of frequency tables and suitable statistics. We compared each findings of power plant area with that of non-plant area by obtaining relative risk for power plant area compared to non-plant area. $\mathrm{p}$ value by fisher's exact test ( $\mathrm{F} p$ value) was also obtained for significantly associated findings with the help of software Epi info version 17.

When internal comparison was done in between villages stratified according to distance in power plant area, we obtained relative risk taking group 3 [8-10km] as comparison group. So that two relative risks were calculated- RR 1 shows the risk associated with people living at $0-3 \mathrm{~km}$ for that finding as compared to $8-10 \mathrm{~km}$ and RR 2 shows the risk associated with people living at $5-6 \mathrm{~km}$ for that finding as compared to $8-10 \mathrm{~km}$.

\section{Observations and Discussion}

Table 1 shows the surveyed households (80 households at each distance and total 240 in each area) and household population. Total surveyed population was 2342, out of which 1163 at coal based power plant area and 1179 at non power plant area. In plant area separate surveyed population at $0-3 \mathrm{~km}$ was 375 , at $5-6 \mathrm{~km}$ was 390 and at 8-10 $\mathrm{km}$ was 398 .

Table 2 shows that $81.3 \%$ of households in the power plant area had at least one ill member in the family while in non-plant area such households were only $23.8 \%$. When compared with distance in power plant area $90 \%$ households at $0-3 \mathrm{~km}$, $82.5 \%$ households at $5-6 \mathrm{~km}$ and $71.2 \%$ households at $8-10 \mathrm{~km}$ had at least one ill member in the family.

While taking whole population, 448 [38.5\%] persons had some kind of illness in power plant area and 99 [8.4\%] persons had some kind of illness in non-plant area. When compared within power plant area 180 person out of 375 [48\%] at $0-3 \mathrm{~km}, 145$ person out of 390 [37.1\%] at $5-6 \mathrm{~km}$ and 123 person out of 398 [30.9\%] were had had some kind of illness. Population living in the power plant area was at 4.59 times more risk of becoming ill. Again within the power plant area 1.55 times more risk to population living at $0-3 \mathrm{~km}$ and a 1.20 times risk to population living at $5-6 \mathrm{~km}$ compared to population living at 8-10 km.

Table 1: Distribution of surveyed households and household population

\begin{tabular}{|l|l|l|l|l|l|}
\hline \multirow{2}{*}{ Surveyed households } & \multicolumn{2}{|l|}{ Study groups in power plant area } & \multicolumn{2}{l|}{ Comparison with non plant area } \\
\cline { 2 - 6 } & $0-3 \mathrm{~km}$ & $5-6 \mathrm{~km}$ & $8-10 \mathrm{~km}$ & Plant area & Non Plant area \\
\hline Households & 80 & 80 & 80 & 240 & 240 \\
\hline Household population & 375 & 390 & 398 & 1163 & 1179 \\
\hline
\end{tabular}

Table 2: Distribution of surveyed households and household population according to any kind of illness in the family members

\begin{tabular}{|l|l|l|l|l|l|l|l|l|}
\hline \multirow{2}{*}{$\begin{array}{l}\text { Family H/o any } \\
\text { kind of illness }\end{array}$} & \multicolumn{4}{|l|}{ Study groups in power plant area } & \multicolumn{3}{|l|}{ Comparison with non plant area } \\
\cline { 2 - 9 } & $\begin{array}{l}0-3 \mathrm{~km} \\
{[\%]}\end{array}$ & $\begin{array}{l}5-6 \mathrm{~km} \\
{[\%]}\end{array}$ & $\begin{array}{l}8-10 \mathrm{~km} \\
{[\%]}\end{array}$ & RR1 & RR2 & $\begin{array}{l}\text { Plant area } \\
\text { Total }\end{array}$ & $\begin{array}{l}\text { Non } \\
\text { area Total }\end{array}$ & $\begin{array}{l}\text { RR, } \\
{[\mathrm{F} p \text { value* }}\end{array}$ \\
\hline Households & $72[90]$ & $66[82.5]$ & $57[71.2]$ & 1.26 & 1.15 & $195[81.3]$ & $57[23.8]$ & $\begin{array}{l}3.42 \\
{[0.000 *]}\end{array}$ \\
\hline $\begin{array}{l}\text { Household } \\
\text { population }\end{array}$ & $180[48]$ & $145[37.1]$ & $123[30.9]$ & 1.55 & 1.20 & $448[38.5]$ & $99[8.40]$ & $\begin{array}{l}4.59 \\
{[0.000 *]}\end{array}$ \\
\hline
\end{tabular}


Table 3: Distribution of total surveyed population as per reasons of illness (multiple response)

\begin{tabular}{|l|l|l|l|l|l|l|l|l|}
\hline \multirow{2}{*}{$\begin{array}{l}\text { Reasons for Family } \\
\text { H/liness }\end{array}$} & \multicolumn{4}{|l|}{ Study groups in power plant area } & \multicolumn{3}{l|}{ Comparison with non plant area } \\
\cline { 2 - 9 } & $\begin{array}{l}0-3 \mathrm{~km} \\
\mathrm{n}=180 \\
{[\%]}\end{array}$ & $\begin{array}{l}5-6 \mathrm{~km} \\
\mathrm{n}=145 \\
{[\%]}\end{array}$ & $\begin{array}{l}8-10 \mathrm{~km} \\
\mathrm{n}=123 \\
{[\%]}\end{array}$ & RR1 & RR2 & $\begin{array}{l}\text { Plant area } \\
\text { Total n=448 } \\
{[\%]}\end{array}$ & $\begin{array}{l}\text { Non Plant } \\
\text { area } \\
\mathrm{n}=99\end{array}$ & $\begin{array}{l}\text { RR,[Fp value*] } \\
\text { [n=1163 \&1179] }\end{array}$ \\
\hline Respiratory & $88[48.9]$ & $71[48.9]$ & $54[43.9]$ & 1.11 & 1.11 & $213[47.5]$ & 38 & $5.68\left[0.000^{*}\right]$ \\
\hline Cardiovascular & $18[10]$ & $15[10.3]$ & $10[8.13]$ & 1.23 & 1.27 & $43[9.6]$ & 18 & $2.42\left[0.001^{*}\right]$ \\
\hline CNS & $8[4.44]$ & $16[11.0]$ & $5[4.07]$ & 1.09 & 2.7 & $29[6.5]$ & 0 & {$\left[0.000^{*}\right]$} \\
\hline Gastrointestinal & $51[28.3]$ & $38[26.2]$ & $26[21.1]$ & 1.34 & 1.23 & $115[25.7]$ & 30 & $3.89\left[0.000^{*}\right]$ \\
\hline Renal & $5[2.8]$ & $4[2.8]$ & $2[1.6]$ & 1.7 & 1.7 & $11[2.5]$ & 4 & $3.05[0.06]$ \\
\hline Musculoskeletal & $38[21.11]$ & $23[16.3]$ & $20[16.2]$ & 1.3 & 0.98 & $81[18.1]$ & 24 & $3.42\left[0.000^{*}\right]$ \\
\hline Reproductive & $22[12.2]$ & $20[13.8]$ & $11[8.94]$ & 1.37 & 1.5 & $53[11.8]$ & 20 & $2.680\left[0.000^{*}\right]$ \\
\hline Skin & $36[20]$ & $22[15.2]$ & $20[16.2]$ & 1.23 & 0.93 & $78[17.4]$ & 19 & $4.160\left[0.000^{*}\right]$ \\
\hline Malignancy/Lump & $5[2.78]$ & $3[2.07]$ & $2[1.63]$ & 1.70 & 1.27 & $10[2.3]$ & 1 & $10.1\left[0.005^{*}\right]$ \\
\hline $\begin{array}{l}\text { Fever (cause not } \\
\text { specified) }\end{array}$ & $18[10]$ & $16[11.0]$ & $12[9.8]$ & 1.02 & 1.13 & $46[10.3]$ & 3 & $7.77\left[0.00^{*}\right]$ \\
\hline $\begin{array}{l}\text { Headache/ } \\
\text { migraine }\end{array}$ & $22[12.2]$ & $16[11.0]$ & $15[12.2]$ & 1.0 & 0.90 & $53[11.8]$ & 15 & $3.58\left[0.00^{*}\right]$ \\
\hline
\end{tabular}

Table 3 shows that illnesses due to any reason were significantly high [Fisher's $p=0.00$ highly significant] in population living in the vicinity of power plant area as compared to non plant area. Among ill, maximum $47.5 \%$ population had respiratory illness. There was 5.68 times risk in the power plant area for respiratory illnesses compared to non-plant area. $25.7 \%$ population had Gastrointestinal illness [RR=3.89], $\quad 18.1 \%$ population had musculoskeletal problems, $17.4 \%$ population had skin problems, $11.8 \%$ had reproductive problems, 9.6\% had cardiovascular illness, 6.5\% had CNS (central nervous system) problems, $2.3 \%$ had malignancy [Figure 1]. When compared with distance in power plant area maximum percentage of illnesses was found at 0 $3 \mathrm{~km}$ compared to $8-10 \mathrm{~km}$. Only illnesses due to CNS causes were more in the population living at 5-6km [Figure 2]. Conrad G. Schneider, [2000] reported that death, hospitalizations, emergency room visits, asthma attacks, and a variety of respiratory symptoms, wet cough, running or stuffy nose and burning etc. are much prevalent in power plant area. ${ }^{[6]}$ Salonen et al. (1995) reported two times greater risk of acute myocardial infarction in people living in power plant area than the rest of the study population ${ }^{.8]}$ A study by Fewthrell, Kaufmann, and Preuss,[2003] and another study by Harada et al also found that signs of central nervous system damage in adults caused by lead and $\mathrm{Hg}$ exposure in power plant area. ${ }^{[9]}$

\section{Pattern of illnesses}

(Coal based power plant area)

The study results show that a number of adverse health hazards can be caused by pollutants that are released into the air or in water bodies nearer to the coal based power plants. Areas closer to the power plant ash pond showed more hazards to the inhabitants. In our study we also found similar pattern. Maximum number of population had respiratory illnesses. Second most common was Gastrointestinal illnesses. Next common reasons for illness were musculoskeletal and skin problems then nonspecific fever and headache [Figure 3]. Ill healths due to Cardiovascular, renal and malignant condition were also found in many people (on upper part of pyramid) but less than respiratory and Gastrointestinal illnesses. In Tennessee Valley Authority Health survey Report, [2009] it is found that within a 1.5 mile radius of the spill participants $12 \%$ had asthma $6 \%$ COPD, and 5\% had MI. Among participants cough 27\%, headache $25 \%$, wheezing $14 \%, 15 \%$ had symptoms of shortness of breath. ${ }^{[7]}$ 


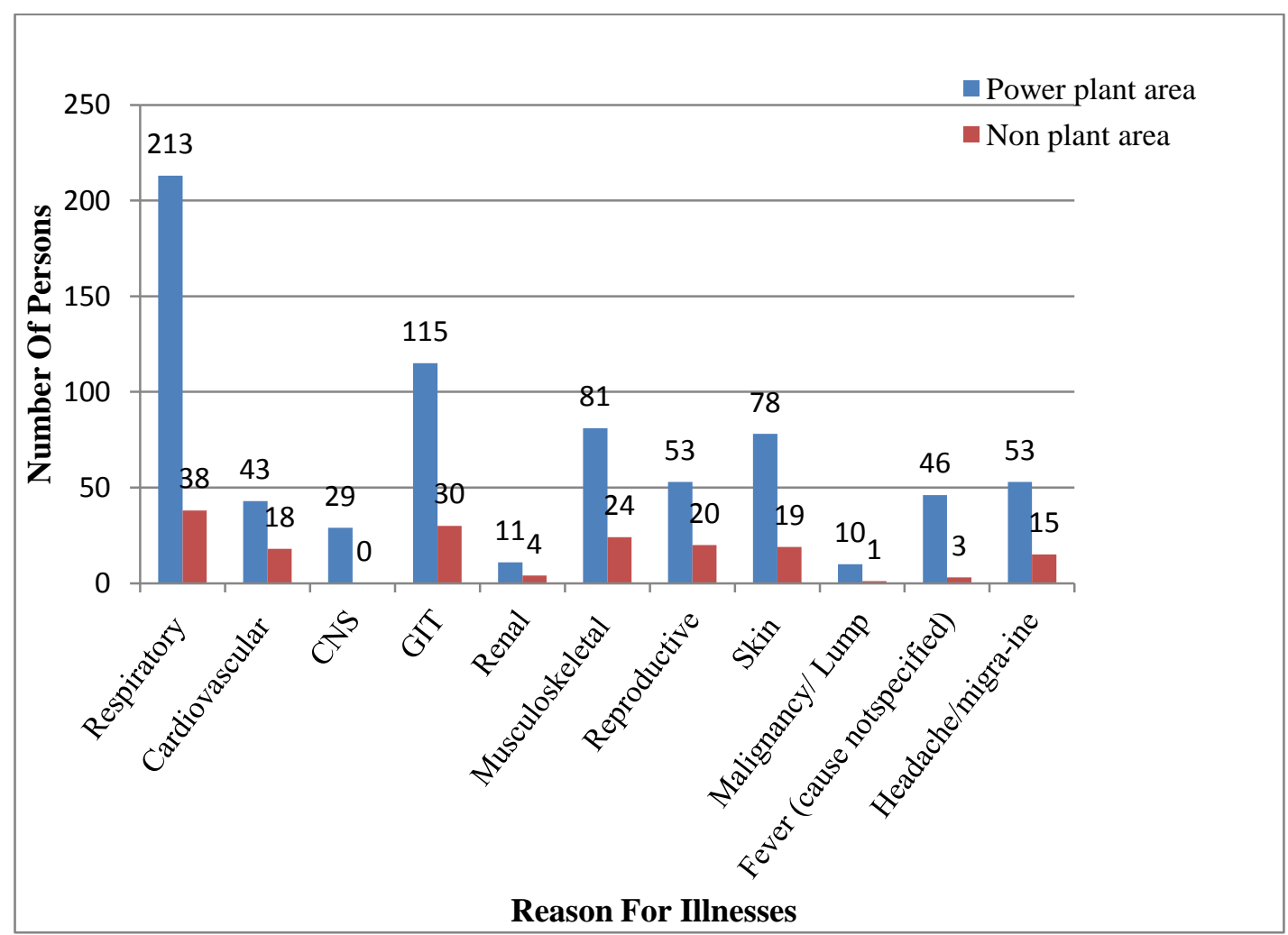

Figure 1: Distribution of illnesses in total surveyed population as per reasons of illness

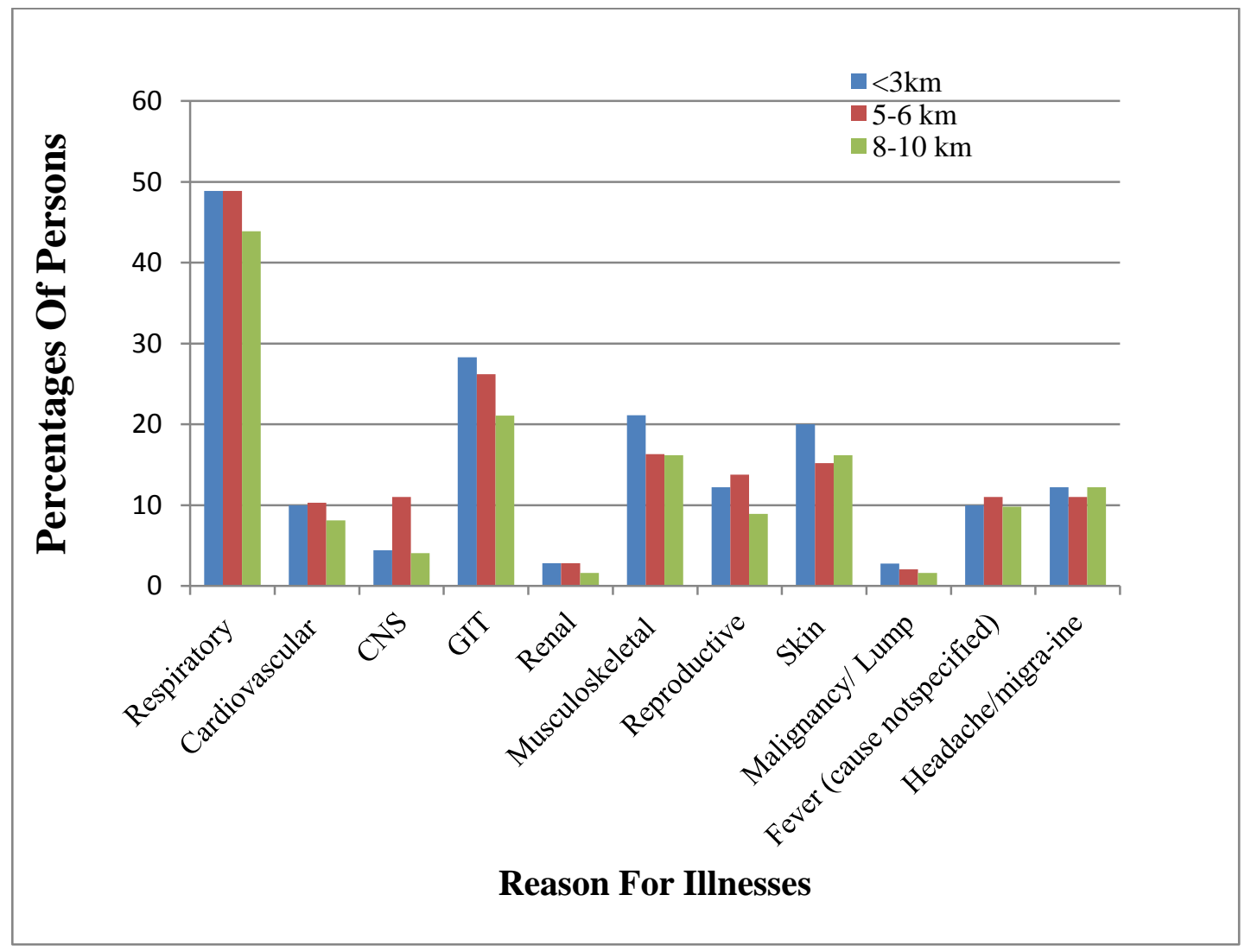

Figure 2: Percentage Distribution of illnesses in total surveyed population as per reasons of illness with distance from coal ash pond 


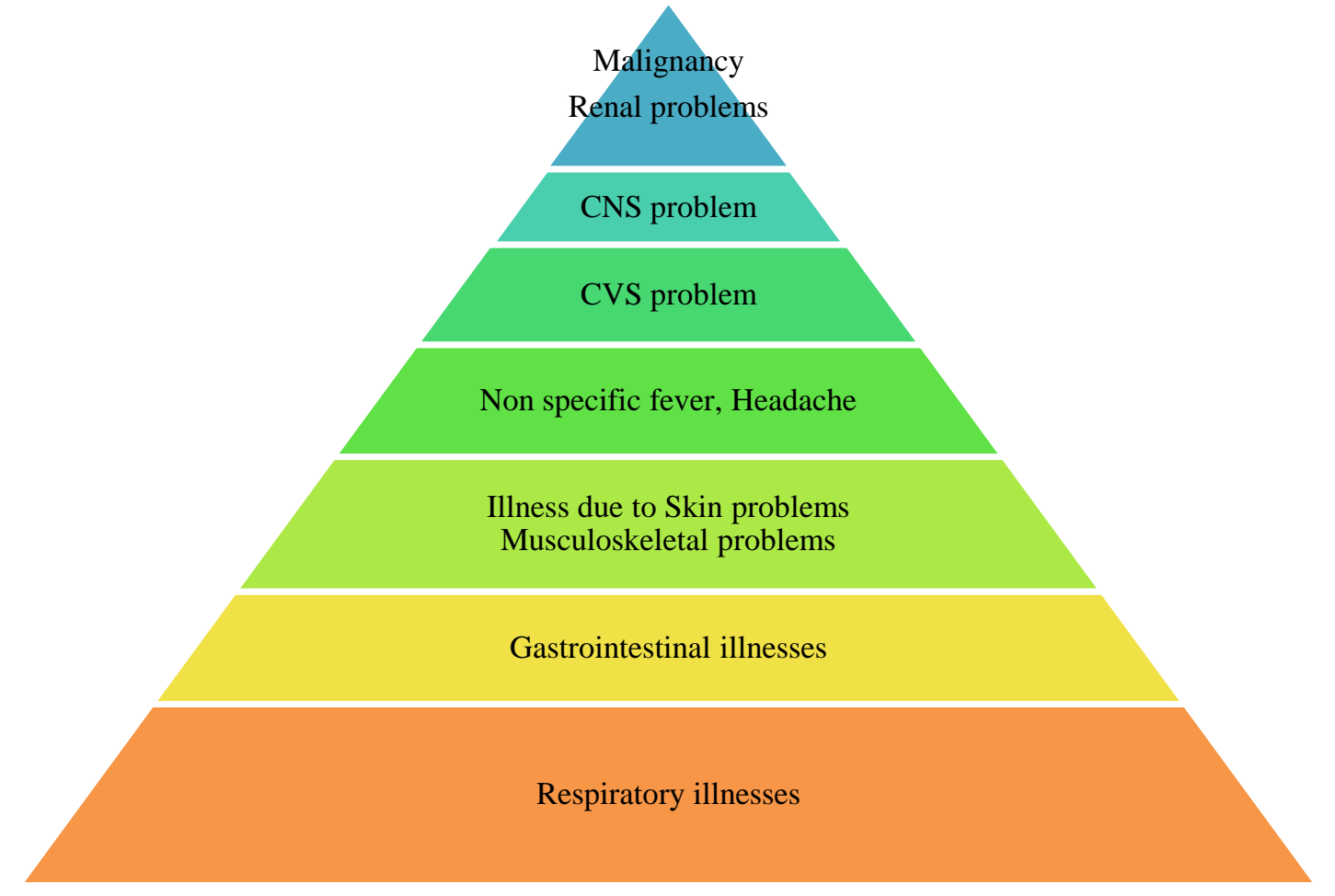

Figure 3: Schematic diagram showing pattern of illnesses in the coal based plant area

\section{Conclusion}

The overall 3 study distances $[0-3 \mathrm{~km}, 5-6 \mathrm{~km}$ and $8-10 \mathrm{~km}]$ showed the health risk. There was found significant difference in occurrence of diseases in power plant area as compared to non-plant area. At the regional scale people living at $0-3 \mathrm{~km}$ distance from Rihand reservoir were relatively at greatest risk, as compared to non plant area. The people living in the vicinity of power plant area are at greater risk of various health hazards due to continuous exposure to various pollutants and all of us are at risk for exposure to power plant pollution as the consequences of emission from power plants are diffused over ten to tens of thousands of miles, tens of years, and tens of millions of victims, thus pose special problem not only to the inhabitants but also to the health managers, administration and policy makers.

So in my view further research with more rigorous work is necessary to completely understand the risks and to implement specific environmental and health measures for these vulnerable communities to mitigate the health problems.

\section{Acknowledgments}

The authors are thankful to Dr. N. A. Toppo, Assistant Professor, Department of Community Medicine, NSCB Medical College Jabalpur, and special thanks to Dr. sambit pradhan, Dr. Vikrant Kabirpanthi, Dr. Pritesh Thakur, PG students Department of community Medicine NSCB Medical College, Jabalpur, MP for their invaluable help in data collection for this study.

\section{References}

1. Mishra U.C. Environmental impact of coal industry and thermal power plants in India $\quad \mathrm{J} \quad$ Environmental Radioactivity, 2004;72(1-2): 35-40 p

2. Parth Das Sharma, Keeping world environment safer and greener, Sept 5 2008.

3. Barbara Gottlieb et al: Coal Ash : the toxic threat to our health and environment: A report from Physicians for social Responsibility and earth justice, Sept 2010

4. Baseline Human Health Risk Assessment For The Standard Mine Site Gunnison County, Colorado: U.S. Environmental 
Protection Agency Region 8, March 19, 2008

5. The energy and resources institute New Delhi India, (Teri 1999)-power plant emission and local health damage

6. Conrad G. Schneider, Clean Air Task Force: Death, Disease \& Dirty Power Mortality and Health Damage Due to Air Pollution from Power Plants October 2000.

7. Laura Connor, Tennessee Valley Authority Health survey Report on coal ash sludge release from Kingston fossil plant on Dec 22 2008: Feb. 252009.

8. Salonen, JT; Seppanen, K; Nyyssonen, K; et al. (1995) Intake of mercury from fish, lipid peroxidation, and the risk of myocardial infarction and coronary, cardiovascular, and any death in Eastern Finnish men. Circulation 91(3):645-655.

9. Fewthrell, L., R. B. Kaufmann, and A. Preuss. Assessing the Environmental Burden of Disease at the National and Local Level: Lead. Environmental Burden of Disease Series 2. Geneva: World Health Organization, 2003.

10. Marco Valenti, Francesco Masedu and Sergio Tiberti Focus on coal power station installations and population health: Ann Ist Super Sanità 2011, Vol. 47, No. 3: 305309. 